\title{
Production and Standardization of Combined Vaccine against Haemorrhagic Septicaemia and Black Quarter
}

\author{
Nivedita Kushram ${ }^{1}$, Rakesh Sharda ${ }^{2}$, Kripa Shankar Misraulia ${ }^{1}$, \\ Sanjay Madhukar Gholap ${ }^{3}$, Daljeet Chhabra ${ }^{2}$, Hemant Mehta ${ }^{2}$ and Rakhi Gangil ${ }^{2 *}$ \\ ${ }^{1}$ Department of Veterinary Medicine, NDVSU, ${ }^{2}$ Department of Veterinary Microbiology, \\ College of Veterinary Science and Animal Husbandry, Mhow -453446, India \\ ${ }^{3}$ Institute of Animal Health and Veterinary Biologicals, Mhow -453446, India
}

*Corresponding author

\section{A B S T R A C T}

\begin{tabular}{|l|}
\hline Ke y w o r d s \\
Combined vaccine, \\
$\begin{array}{l}\text { Clostridium } \\
\text { chauvoei, } \\
\text { Black quarter, } \\
\text { Haemorrhagic } \\
\text { septicaemia, } \\
\text { Pasteurella } \\
\text { multocida }\end{array}$ \\
\hline Article Info \\
\hline $\begin{array}{l}\text { Accepted: } \\
\text { 20 June } 2020 \\
\text { Available Online: } \\
\text { 10 July } 2020\end{array}$ \\
\hline
\end{tabular}

\section{Introduction}

Livestock sector has a significant contribution in Indian economy and it also plays an important role in prosperity of rural India. India is the largest milk producer in the world with annual production of 165.4 million tons in 2017 (Singh, 2018). It can continue to hold this position if some of the diseases affecting the productivity of the animals is taken care

\begin{abstract}
The enormosity of infectious diseases continues to be a major constraint to the economical viability of livestock industry. Combined vaccines against more than one infectious disease reduce the cost, time, and labour of vaccination. In present study, formalized vaccines against Haemorrhagic Septicaemia and Black Quarter diseases were prepared using $\mathrm{P}_{52}$ strain of Pasteurella multocida and Clostridium chauvoei strain 49. Different proportions of these two vaccines were mixed to formulate various groups of combined vaccines, which were subsequently standardized for sterility, safety and potency. Amongst all combinations a group containing $1 \mathrm{ml}$ of H.S. casein sucrose yeast extract agar washed vaccine and $4 \mathrm{ml}$ of B.Q. thioglycolate broth and culture vaccine with shaking was found most efficacious in our study. This combined vaccine conferred $100 \%$ protection against H.S. disease and $75 \%$ against B.Q. disease in rabbits and guinea pigs, respectively in potency test performed for individual vaccines. The study also revealed that casein sucrose yeast agar and fluid thioglycolate broth are better medium for cultivation of $P$. multocida and $\mathrm{Cl}$. chauvoei. Enhanced growth of $\mathrm{Cl}$. chauvoei was observed when incubated on a shaker as compared to static culture.
\end{abstract}

off. There are number of bacterial, viral and fungal pathogens which cause severe diseases in cattle and buffaloes affecting animal health and lead to decreased milk production.

In India haemorrhagic septicaemia (H.S.) and black quarter (B.Q) constitute the major bacterial diseases of ruminants and have an adverse effect on the economic viability of the livestock industry. Haemorrhagic Septicaemia 
is an acute and fatal septicaemic disease of cattle and buffaloes, primarily caused by serotype B:2 and E:2 of Pasteurella multocida in Asia including India.

The disease is endemic and is of great economic importance (OIE, 2002); the annual losses exceeding 10 million rupees per annum in India (Singh et al., 1996). Black Quarter is a predominant disease of cattle, goat and sheep caused by Clostridium chauvoei. It is characterized by development of focal gangrenous and emphysematous myositis and gives rise to crepitating and serohaemorrhagic swelling in gluteal muscles (Radostits et al., 2009).

Vaccination is an important tool for controlling infectious diseases. Regular prophylactic vaccination of animals against infectious diseases in developing countries has become an important input to maintain milk production and to reduce economic losses.

In an exercise to reduce the cost of vaccination, many workers attempted to prepare and use combined vaccines (Salt et al., 1996). Present work has been aimed to develop and standardize a combined vaccine against H.S. and B.Q. diseases.

\section{Materials and Methods}

\section{Experimental animals}

Apparently healthy laboratory animals including Swiss albinomice (approx.18-20g body weight), albino rabbits (approx. $2 \mathrm{~kg}$ body weight) and guinea pigs (approx. 300$450 \mathrm{~g}$ body weight) of either sex were procured from the Institute of Animal Health and Veterinary Biological (IAH and VB), Rasalpura, Mhow (M.P.).This study was approved by the Institutional Animal Ethics Committee.

\section{Seed strains}

The seed of Pasteurella multocida strain $\mathrm{P}_{52}$ was procured from I.V.R.I. Izatnagar, Bareilly (U.P.) India and Clostridium chauvoei strain 49was obtained from the Institute of A.H. and Veterinary Biologicals, Mhow.

\section{Preparation of seed stock}

The freeze-dried culture of $P$. multocida $\mathrm{P}_{52}$ strain was reconstituted in normal saline solution and inoculated on blood agar plate. Purity was tested by Gram's staining followed by subculture on blood agar slant and incubated at $37^{\circ} \mathrm{C}$ for $18 \mathrm{hrs}$. The seed strain of Clostridium chauvoei strain 49 was cultured in Fluid thioglycolate broth (FTB) (Himedia, India) and incubated for 24-48 hrs.at $37^{\circ} \mathrm{C}$ and purity was confirmed by Gram's staining. Seed stock of both strains was preserved at $4^{\circ} \mathrm{C}$.

\section{Preparation of production flask of} Pasterulla multocida for $\mathrm{HS}$ vaccine

Pasteurella multocida $\mathrm{P}_{52}$ strain was inoculated in nutrient broth followed by Seed culture of incubation at $37^{\circ} \mathrm{C}$ for $18 \mathrm{hrs}$. Roux flasks of nutrient agar (Himedia, India) and casein sucrose yeast extract (CSY) agar were inoculated with this over night broth culture and incubated at $37^{\circ} \mathrm{C}$ for $18 \mathrm{hrs}$. The bacterial growth was harvested in $0.5 \%$ normal saline by using sterile rolling glass beads. Subsequently the harvest was filtered through muslin cloth to remove coarse agar particles and glass beads and purity were examined with Gram's staining.

\section{Preparation of production flask of Clostridium chauvoei for $B Q$ vaccine}

The production flasks, each of $4 \mathrm{~L}$ volume, containing Fluid thioglycolate broth (Himedia, India) and a commercial BQ 
vaccine medium (Himedia, India)were inoculated with seed culture of Clostridium chauvoei strain 49 followed by the addition of $30 \mathrm{ml} \mathrm{50 \%} \mathrm{glucose} \mathrm{solution} \mathrm{in} \mathrm{each} \mathrm{flask.} \mathrm{The}$ production flasks were divided in to two batches. One batch was incubated in static condition (without shaking) at $37^{\circ} \mathrm{C}$ for 7 days, while the other batch of production flask was incubated at $37^{\circ} \mathrm{C}$ in a shaker incubator at speed of $120 \mathrm{rpm}$ for 7 days.

\section{Inactivation by formalization}

The formal saline solution $(0.5 \%, \mathrm{v} / \mathrm{v})$ was added at final concentration in both bacterial suspensions. For complete inactivation of Pasteurella multocida the harvest was kept in the incubator at $37^{\circ} \mathrm{C}$ for $2-3$ days while to prepare $\mathrm{BQ}$ anaculture (bacteria + toxoid) vaccine up to 7 days incubation was given at same temperature.

\section{Determination of antigenic mass}

Antigenic mass of Pasteurella multocida grown in nutrient agar and CSY agar was determined as per prescribed method (Cruickshank et al., 1975). Dry weight of $P$. multocida was found higher in CSY agar than nutrient agar and, therefore, formalized CSY agar washed H.S. bacterin was used to prepare combined vaccine against H.S. and B.Q.

\section{Preparation of combined HS and BQ vaccine}

Four groups of combined H.S and B.Q. vaccines were prepared by mixing different proportions of individual formalized bacterial suspensions of $\mathrm{P}$. multocida and $\mathrm{Cl}$. chauvoei prepared as above to give a final volume of $5 \mathrm{ml}$ of vaccine in each group (Table1). Alum solution was added in each group of combined vaccine at a final concentration of $1 \%$.

\section{Standardization of combined vaccine}

All groups of combined vaccines were standardized as per described procedure for H.S. and B.Q. vaccine (Kher, 1991; Indian Pharmacopeia 2007; IVRI 1977; OIE 2012).

\section{Sterility test}

Sterility of each group of combined vaccine was confirmed by inoculating in nutrient broth, Robertson cooked media and Sabouraud's broth (Himedia, India). The inoculated media were incubated at $37^{\circ} \mathrm{C}$ for up to 5 days and growth/turbidity, if any, was recorded.

\section{Safety test}

The safety test was conducted by injecting 1 and $2 \mathrm{ml}$ of combined vaccine from each group in six guinea pigs and two rabbits, respectively. The animals were observed for any local or systemic reaction and/or mortality up to 5 days.

\section{Potency test}

\section{H.S. vaccine}

The potency test of combined vaccine against H.S. disease was conducted in rabbits. Twenty four rabbits were divided into four equal groups $\left(A_{H}\right.$ to $\left.D_{H}\right)$. All animals within each group received $2 \mathrm{ml}$ of combined vaccine of respective group (A to $A_{H}, B$ to $B_{H}$.) by $\mathrm{I} / \mathrm{M}$ route on day 1 and a booster dose of equal volume on day 14 of experiment. Two rabbits kept as control were injected with equal volume of sterile nutrient broth $\mathrm{I} / \mathrm{M}$ on day 1 and 14 . On $21^{\text {st }}$ day all rabbits were challenged by injecting $0.2 \mathrm{ml}$ of $18 \mathrm{~h}$ old broth culture of virulent $P$. multocida (Table2) and observed for any untoward clinical symptoms/mortality upto 5 d.p.i. 


\section{B.Q. vaccine}

The potency test of combined vaccine against B.Q. disease was evaluated in guinea pigs. Thirty two guinea pigs were divided into four equal groups $\left(A_{B}\right.$ to $\left.D_{B}\right)$. All animals within each group were injected $3 \mathrm{ml}$ of combined vaccine of respective group (A to $A_{B}, B$ to $B_{B}$.) by $S / C$ route on day 1 and a booster dose of equal volume on day 14 of experiment. Four guinea pigs kept as control were injected with equal volume of sterile nutrient broth S/C on day 1 and 14 . On $21^{\text {st }}$ day all guinea pigs were challenged by injecting 25 viable spores of $\mathrm{Cl}$. chauvoei along with $0.2 \mathrm{ml}$ of $0.5 \% \mathrm{CaCl}_{2}$ (Table 3) and observed for any untoward clinical symptoms/mortality upto 5 d.p.i.

\section{Results and Discussion}

Haemorrhagic septicaemia and Black quarter are the most common bacterial diseases affecting cattle and buffalo in India. Prophylactic programme is carried out by vaccination against various types of infectious diseases. Combined Haemorrhagic Septicaemia and Black Quarter vaccine, which was found to confer dependable levels of immunity in cattle, was used in zones where both diseases existed (Bharsefat $e t$ al., 1977). This research was conducted to prepare and standardize a combined vaccine against these two diseases.

In the present study, the antigenic mass of $P$. multocida on CSY agar was found to be higher $(9.8 \mathrm{mg} / \mathrm{ml})$ than on Nutrient agar $(7.8$ $\mathrm{mg} / \mathrm{ml})$. Better growth of $P$. multocida B:6 was also observed in CSY and BHI broth compared to Nutrient broth on dry weight basis (Mahmood 2001, Shah 2007). An antigenic mass of $3.35-3.68 \mathrm{mg} / \mathrm{ml}$ was obtained in CSY broth while only 0.45-0.62 $\mathrm{mg} / \mathrm{ml}$ in nutrient broth (Kavitha et al, 2011), indicating that CSY broth is a better medium for producing H.S. vaccine, which is in concurrence to our results.

The B.Q. vaccine was prepared by cultivating Cl. chauvoei in FTB and a commercial B.Q.vaccine media. Better growth was observed in FTB than the latter. Better growth of $\mathrm{Cl}$. perfringens for vaccine production was obtained in reinforced Clostridium media than nutrient broth, in terms of higher biomass and maximum haemolytic units (Bhatti, 2005).

Incubation of $\mathrm{Cl}$. chauvoei in FTB with shaking at a speed of $120 \mathrm{rpm}$ for 7 days at $37^{\circ} \mathrm{C}$ yielded better growth of bacterium than when incubated as static culture. Similar to our findings it was observed that the biomass production of clostridia increased twice on incubation with shaking (Shoshtary et al., 2007).

Table.1 Different groups of H.S. and B.Q. combined vaccine

\begin{tabular}{|l|l|l|}
\hline Group & Combinations & Volume \\
\hline Group A & H.S. CSY agar washed vaccine & $1 \mathrm{ml}$ \\
\cline { 2 - 3 } & B.Q. Fluid thioglycolate broth vaccine without shaker & $4 \mathrm{ml}$ \\
\hline \multirow{2}{*}{ Group B } & H.S. CSY agar washed vaccine & $1 \mathrm{ml}$ \\
\cline { 2 - 3 } & B.Q. Fluid thioglycolate broth vaccine with shaker & $4 \mathrm{ml}$ \\
\hline \multirow{2}{*}{ Group C } & H.S. CSY agar washed vaccine & $1.5 \mathrm{ml}$ \\
\cline { 2 - 3 } & B.Q. Fluid thioglycolate broth vaccine without shaker & $3.5 \mathrm{ml}$ \\
\hline \multirow{2}{*}{ Group D } & H.S. CSY agar washed vaccine & $1.5 \mathrm{v} \mathrm{ml}$ \\
\cline { 2 - 3 } & B.Q. Fluid thioglycolate broth vaccine with shaker & $3.5 \mathrm{ml}$ \\
\hline
\end{tabular}


Table.2 Potency test of combined vaccines against H.S. in rabbits

\begin{tabular}{|c|c|c|c|c|c|}
\hline Group of combined vaccine & Group A & Group B & Group C & Group D & Control \\
\hline Total no. of animals & $6\left(\mathrm{~A}_{\mathrm{H}}\right)$ & $6\left(\mathrm{~B}_{\mathrm{H}}\right)$ & $6\left(\mathrm{C}_{\mathrm{H}}\right)$ & $6\left(D_{H}\right)$ & 2 \\
\hline $\begin{array}{l}\text { Primary Dose (I/M) } \\
\text { (day 1) }\end{array}$ & $2 \mathrm{ml}$ & $2 \mathrm{ml}$ & $2 \mathrm{ml}$ & $2 \mathrm{ml}$ & $\begin{array}{l}2 \mathrm{ml} \text { sterile } \\
\text { nutrient broth } \\
\mathrm{I} / \mathrm{M}\end{array}$ \\
\hline $\begin{array}{l}\text { Booster Dose (I/M) } \\
\text { (day 14) }\end{array}$ & $2 \mathrm{ml}$ & $2 \mathrm{ml}$ & $2 \mathrm{ml}$ & $2 \mathrm{ml}$ & $\begin{array}{l}2 \mathrm{ml} \text { sterile } \\
\text { nutrient broth }\end{array}$ \\
\hline $\begin{array}{l}\text { Challenge with18 hrs old } \\
\text { culture of } P \text {. multocida strain } \\
P_{52}(\mathbf{I} / \mathrm{M})(\text { day } 21)\end{array}$ & $0.2 \mathrm{ml}$ & $0.2 \mathrm{ml}$ & $0.2 \mathrm{ml}$ & $0.2 \mathrm{~m} \mathrm{l}$ & $0.2 \mathrm{ml}$ \\
\hline
\end{tabular}

Table.3 Potency test of combined vaccines against B. Q. in Guinea pigs

\begin{tabular}{|l|c|c|c|c|l|}
\hline $\begin{array}{l}\text { Group of combined } \\
\text { vaccine }\end{array}$ & Group A & Group B & Group C & Group D & Control \\
\hline Total no. of animals & $8\left(\mathrm{~A}_{\mathrm{B}}\right)$ & $8\left(\mathrm{~B}_{\mathrm{B}}\right)$ & $8\left(\mathrm{C}_{\mathrm{B}}\right)$ & $8\left(\mathrm{D}_{\mathrm{B}}\right)$ & 4 \\
\hline $\begin{array}{l}\text { Primary Dose (day 1) } \\
\text { (S/C) }\end{array}$ & $3 \mathrm{ml}$ & $3 \mathrm{ml}$ & $3 \mathrm{ml}$ & $3 \mathrm{ml}$ & $\begin{array}{l}3 \mathrm{ml} \text { sterile nutrient } \\
\text { broth }\end{array}$ \\
\hline $\begin{array}{l}\text { Booster Dose(day 14) } \\
\text { (S/C) }\end{array}$ & $3 \mathrm{ml}$ & $3 \mathrm{ml}$ & $3 \mathrm{ml}$ & $3 \mathrm{ml}$ & $\begin{array}{l}3 \mathrm{ml} \text { sterile nutrient } \\
\text { broth }\end{array}$ \\
\hline $\begin{array}{l}\text { Challenge with 25 viable } \\
\text { spores of Cl. chauvoei+ } \\
\text { 0.2 ml of 5\% Cacl } \mathbf{2}(\mathbf{I} / \mathbf{M}) \\
\text { (day 21) }\end{array}$ & $0.2 \mathrm{ml}$ & $0.2 \mathrm{ml}$ & $0.2 \mathrm{ml}$ & $0.2 \mathrm{ml}$ & $0.2 \mathrm{ml}$ \\
\hline
\end{tabular}

S/C - Subcutaneous, I/M - Intramuscular

Fig.1 Results of potency test of different groups of combined vaccine

Against Haemorrhagic septicaemia in rabbits

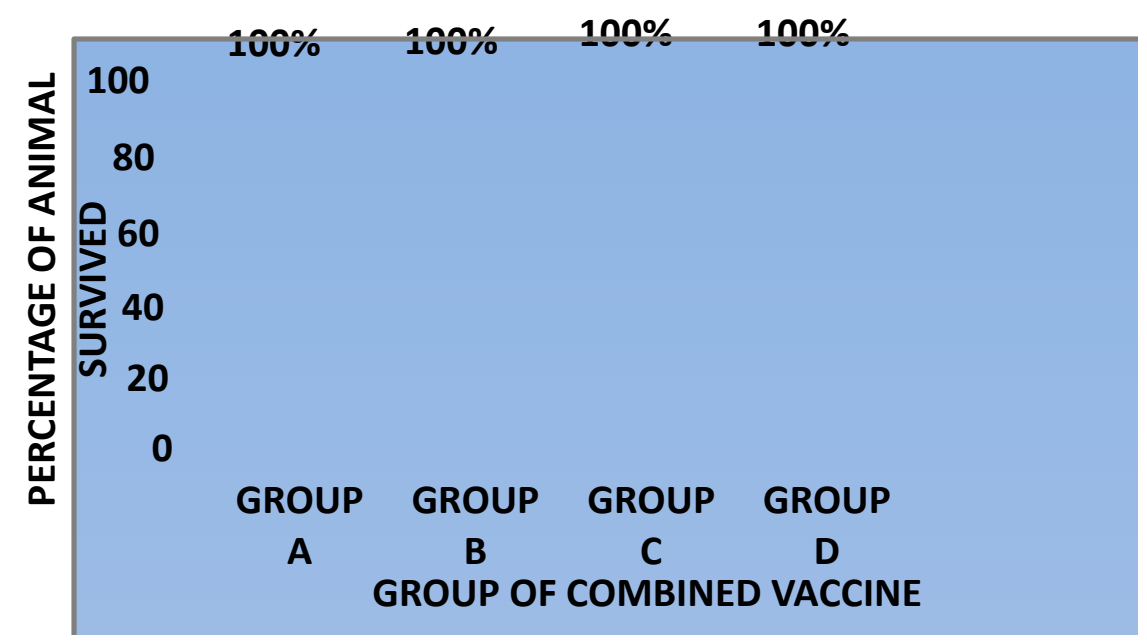


Fig.2 Result of potency test of different groups of combined vaccine against Black quarter in guinea pigs

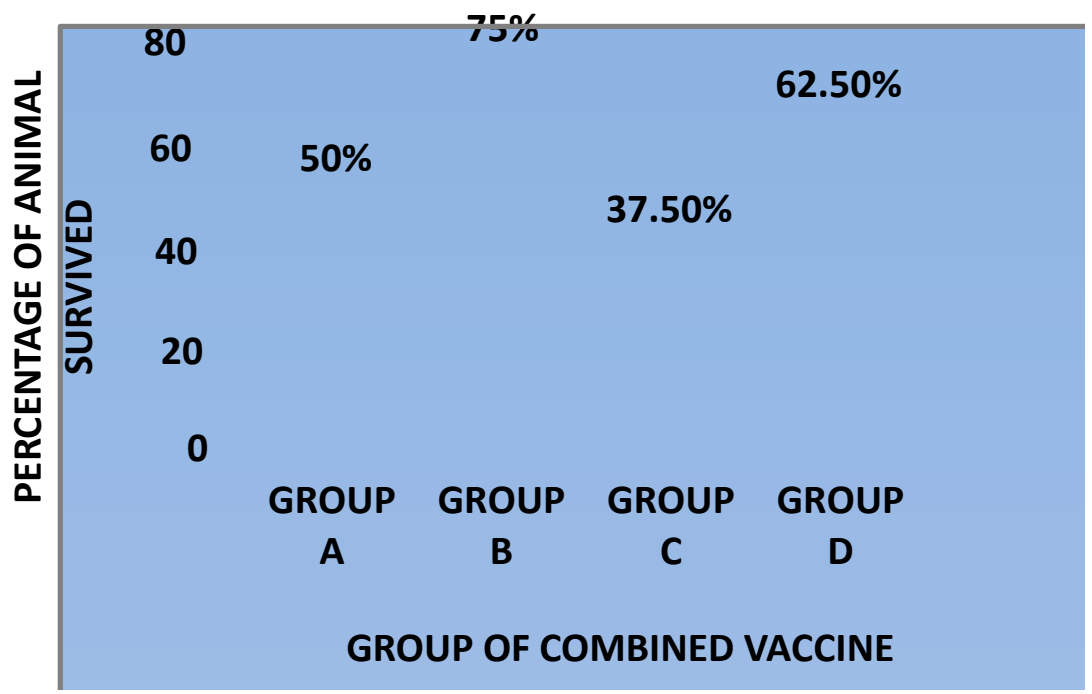

In the present investigation, different formulations of combined H.S. and B.Q. formalised vaccines along with alum (1\% final concentration) as an adjuvant were prepared to give a final volume of $5 \mathrm{ml}$ and further standardized as per standard procedures. The combined vaccines of all four groups were tested for sterility, safety and potency. The results of potency test are presented in figure 1 and figure 2. Some researchers also prepared and standardized combined H.S. and B.Q. vaccines (Sinha and Prasad 1973; Srivastava et al., 1975; Srinivasan et al., 2001; Reddy et al., 2001).All the groups of combined vaccine were found safe and sterile. Anaphylactic reaction was also not observed against any of the combined vaccine, which is in agreement to others (Jabbari et al., 2008).

Amongst all groups, group B combined vaccine containing $1 \mathrm{ml} \mathrm{H.S.} \mathrm{Casein} \mathrm{sucrose}$ yeast extract agar washed formalized vaccine and $4 \mathrm{ml}$ B.Q. Fluid thioglycolate broth formalized anaculture vaccine with shaking was found most efficacious in our study. This combined vaccine conferred $100 \%$ protection against H.S. disease and $75 \%$ against B.Q. disease in rabbits and guinea pigs (figure 1 and figure 2), respectively in potency test performed for individual vaccines. In another study, H.S. agar washed alum precipitatedB.Q. broth vaccine provided absolute protection in vaccinated calves against a fatal challenge infection of the homologous strain of P. multocida and Cl. Chauvoei (Sinha and Prasad, 1973). Some studies observed that the performance of oil adjuvanted vaccines containing $P$. multocida and $\mathrm{Cl}$. chauvoei antigen in comparison with individual component vaccines; combined vaccine provided better immunity than individual vaccine (Srivastava et al., 1975; Reddy et al., 2001). Combined vaccines were found potent and induced a sustainable seroconversion against individual infectious agent (Jang et al., 2009; Altaf et al., 2012).

In the present study, group B vaccines gave $100 \%$ (6/6 survived) protective against virulent $P$. multocida and $75 \%$ (6/8 survived) against $\mathrm{Cl}$. chauvoei in rabbits and guinea pigs, respectively. This may be attributed to lower antigenic ratio of $\mathrm{Cl}$. chauvoei and its 
toxoids in the combined vaccine. This can be overcome either by increasing volume of B.Q. anaculture vaccine with effort to concentrate protection unit (minimum $10^{4} / \mathrm{dose}$ ) of H.S. vaccine in lesser volume or by increasing antigenic mass of Cl.chauvoei anaculture in above vaccine.

This study conclude that a combined vaccine for $\mathrm{HS}$ and BQ consisting of $1 \mathrm{ml}$ of CSY agar washed $P$. multocidabacterin and $4 \mathrm{ml}$ of FTB cultivated $\mathrm{Cl}$. chauvoei anaculture with shaking was found most potent in protecting against virulent bacterial infection in experimental animals. Further studies also suggested that potency test of combined vaccine should be made in natural host that is cattle and buffalo. Long-term studies are also required to determine the duration of immunity against two diseases.

\section{References}

Altaf, I., Siddique, M., Muhammad, K., Irshad, M. and Khan, M.Z. 2012. Antibody response of rabbit to combined H. S. and F.M.D.virus vaccine. Journal of Animal and Plant Sciences, 22: 501-504.

Bharsefat, M. and Firouzi, S.H. 1977. Progress in control of Haemorrhagic Septicemia (Pasteurellosis) in cattle in Iran. Office of International epizootics,Paris, France. (87): 621-625.

Bhatti, S. 2005. Studies on various growth conditions for improved biomass of clostridium perfringens vaccine production and immunogenicity. $\mathrm{PhD}$ Thesis, Sindh Agriculture University, Tandojam, The Pakistan.

Cruickshank, R.,Duguid, J.P., Marmion, B.P., Swain, R.H.A. 1975. In: Text Book of Medical Microbiology.12th ed. (11): 308.

Indian Pharmacopeia. 2007. Biological Veterinary Monograph, pp. 2221-2236.
IVRI. 1977. Manual of Veterinary Biological Products, Production and Testing, Division of Biological Products, IVRI, Izatnagar. pp. 3-18.

Jabbari, A.R., Jula, M., Reza, G., Lngrudi, P.C. and Reza, M.S. 2008.Preparation and evaluation of Improved blackleg and hemorrhagic septicemia vaccine.Archives of Razi Institute, pp. 36.

Jang, H., Kwak, H.Y., Park, M.S., Youn, S.H. and Moon, S.C. 2009. Stability and safety study for establishing the shelf life of anthrax blackleg vaccine. Korean Journal of Veterinary Public Health, 33: $15-20$.

Kavitha, K., Sunitha, G., Krishnamohan, A., Hanmanth,V. and Reddy G. 2011. Effect of Antigenic Mass on the Efficacy of Haemorrhagic septicaemia vaccine.Indian Veterinary Journal, 88 (10): 11-13.

Kher, R.L. 1991. Veterinary Biologicals and their uses. Indian Council of Agriculture Research, New Delhi, pp. 14-17.

Mahmood, I. 2001. Evaluation of growth condition for an improved biomass of Pasteurella multocida vaccine production and immunogenicity. $\mathrm{PhD}$ Thesis, Sindh Agriculture University, Tandojam, The Pakistan.

OIE. 2002. Manual of diagonstic tests and vaccines for terrestrial animals. Office of International epizootics, Paris, France.

OIE. 2012. Manual of diagonstic tests and vaccines for terrestrial animals. Office of International epizootics,Paris, France. Chapter 2.4.12.

Radostits, O.N., Gay, C.C.K.,Hinchcliff, W. and Constable, P.D. 2009. In: Veterinary Medicine- A text book of the diseases of cattle, horses, sheep, pigs and goats. $10^{\text {th }}$ ed. Saunders, Philadelphia and Elsevier, Noida.pp. 827-830. 
Reddy, G.S., Ananda, K. and Srinivasan, V.A. 2001. Performance of oil adjuvant combined vaccine cintaining FMD, Rabies, Pasteurella multocida and Clostridium chauvoei antigens. Indian Veterinary Journal,78: 990-993.

Salt, S., Cox, S.J., Barnett, P.V. andDani,P. 1996. Emergency vaccination of sheep against foot and- mouth disease: protection against disease and reduction in contact transmission. Vaccine; pp.1858-1868.

Shah, S.A.H. 2007. A study on the influence of physic-biochemical agent on the growth and other properties of Pasteurella multocida. PhD Thesis, Sindh agriculture university,Tandojam, The Pakistan.

Shoshtary, M., Langroudi, R.P., Abdolmohammmadi, L. and Jabbari, A. 1973.Preparation of concentrated blackleg vaccine.Archives of Razi Institute, 62: 165-169.

Singh, A. 2018.Current Livestock Production Statistics of India. http: //www. vetextension.com/current-livestock- animal-husbandry-statistics-india.

Singh, V.P., Kumar, A.A., Srivastava, S.K. and Rathore, B.S. 1996. Significance of Haemorrhagic Septicaemia in Asia; India. International Workshop on diagnosis and control of HS. Bali, Indonesia. pp. 28-29.

Sinha, A.K. and Prasad, L.B.M. 1973. An Experimental study with combined vaccines against Haemorrhagic Septicemia and Black Quarter. British Veterinary Journal, 129: 175.

Srinivasan, V.A., Reddy, G.S., Rao, K.A. and Kihm, U. 2001. Serological response of bovines to combined vaccine containing Foot and Mouth Disease virus, Rabies virus, Pasteurellamultocidaand Clostridium chauvoeiantigens. Veterinary Arhiv, 71: 37-45.

Srivastava, N.C., Harbola, P.C. and Khera, S.S. 1975. Preliminary observations on combined vaccination against $\mathrm{HS}$ and BQ. Indian Veterinary Journal, 53: 168-172.

\section{How to cite this article:}

Nivedita Kushram, Rakesh Sharda, Kripa Shankar Misraulia, Sanjay Madhukar Gholap, Daljeet Chhabra, Hemant Mehta and Rakhi Gangil 2020. Production and Standardization of Combined Vaccine against Haemorrhagic Septicaemia and Black Quarter. Int.J.Curr.Microbiol.App.Sci. 9(07): 2534-2541. doi: https://doi.org/10.20546/ijcmas.2020.907.297. 